\title{
How Do the Banks Determine Regulatory Capital, Risk, and Cost Inefficiency in Bangladesh?
}

\author{
Mohammad Morshedur RAHMAN', Md. Ali Arshad CHOWDHURY², Syed MOUDUD-UL-HUQ³
}

Received: September 01, 2020 Revised: October 26, 2020 Accepted: November 05, 2020

\begin{abstract}
This study examines simultaneous relationships between regulatory capital, risk, and cost-inefficiency for a sample of 30 commercial banks in Bangladesh from 2006 to 2018. To conduct the analysis, we used the Generalized Methods of Moments (GMM) in an unbalanced panel data framework. The empirical results show that there is a negative and significant relationship between capital regulation and credit, and overall risk. It is also evident from the results that the capital adequacy ratio is positively and significantly related to default risk and liquidity risk. Therefore, higher capitalized banks take an effort to prevent more credit risk and promote financial stability by reducing liquidity risk. Results also report that banks have been characterized as inefficient, less capitalized, and high risk. On the other hand, efficient banks are more stable but have a high level of liquidity risk. Besides, from the size of the bank, large banks are defined as having lower regulatory capital, are more risk seekers but stable with higher cost-efficiency. Notably, higher capitalized banks are more profitable and cost-efficient by reducing risk. Finally, this study also provides some insightful policy suggestions to the stakeholders.
\end{abstract}

Keywords: Risk, Capital Regulation, Cost Inefficiency, Generalized Methods of Moments, Commercial Banks

JEL Classification Code: G17, G21, D24, D22, F20

\section{Introduction}

It is revealed from the continuous financial crises around the world that banks usually take more risks. It is also observed from the crisis that the financial system and real economy are affected by such a series of crises (Deelchand \& Padgett, 2009). Though banks and the financial system in Bangladesh were not affected by the financial crises; however, due to the crisis, the banking system has become more integrated. Technological advancement and continuous changes in regulations have contributed to the process of financial integration. As a result, competition has increased in the financial institutions.

${ }^{1}$ First Author. Department of Accounting, University of Chittagong, Chittagong, Bangladesh. Email: mmrais@cu.ac.bd

${ }^{2}$ Department of Accounting, University of Chittagong, Chittagong, Bangladesh. Email: arshad@cu.ac.bd

${ }^{3}$ Corresponding Author. Department of Accounting, Mawlana Bhashani Science and Technology University, Bangladesh [Postal Address: Tangail-1902, Bangladesh] E-mail: moudud_cu7@mbstu.ac.bd

(c) Copyright: The Author(s)

This is an Open Access article distributed under the terms of the Creative Commons Attribution Non-Commercial License (https://creativecommons.org/licenses/by-nc/4.0/) which permits unrestricted non-commercial use, distribution, and reproduction in any medium, provided the original work is properly cited.
Due to increased competition and integration, the focus has been on the necessity of improved efficiency in financial institutions. That is, the emphasis is on the best practices that all banks are forced to adopt, as such, in the short run, banks are forced to take excessive risks, thus increasing competition in the banking industry (Danthine et al., 1999; Fiordelisi, Marques-Ibanez, \& Molyneux, 2011; Hellmann, Murdock, \& Stiglitz, 2000). This is because banks lose their market share due to increased competition and their charter value decrease. Salas and Saurina (2003) and Goddard and Wilson (2009) argued that a decrease in charter value encourages banks to take more risks. Regulators in every country are trying to offset this by imposing capital adequacy ratio as capital regulation (Altunbas et al., 2007; Fiordelisi et al., 2011). As a result of pressure from regulators and markets, banks in Bangladesh are under pressure to raise their capital adequacy ratio. In this situation, several studies have focused on the effect of capital on bank risk. Recent bank crises have focused on the necessity for further examination of the determinants of bank risk in a situation of increased bank efficiency and lower level of bank capital (Festic, Kavkler, \& Repina, 2011).

Fiordelisi et al. (2011) argue that banks with a low level of efficiency may try to boost returns by decreasing their 
operating standards, for instance, less rigorous supervision of credit. They also argue that changes in bank risk may affect the efficiency of banks. For instance, if there is an increase in bank risk then it temporally leads to a reduction in cost-efficiency which involves a high level of costs to deal with a high level of non-performing loans. Besides, by following Fiordelisi et al. (2011), in this paper we focus on some important issues in the banking sector in Bangladesh. Among several issues, we focus on the following issues. First, we examine the determinants of bank risk-taking behavior in Bangladesh. Second, the relationship between risk-taking and inefficiency is assessed. Third, we examine the impact of capital regulation on the trade-off between risk-taking and efficiency. For instance, efficient banks may be lightly capitalized and they do not have any incentive to raise their capital in accordance with loans and investments. This is because a high level of efficiency offers banks with a buffer to enhance capital if needed. Alternatively, inefficient banks may hold lower level of capital and try to balance between lower funding through expensive capital and higher operating costs. Inefficient banks may raise their capital while simultaneously raising their level of risk. In the same way, banks with a high level of capital might be efficient and have no incentive to raise more capital while raising their risk level or capital may be costly and to maximize the revenue they may increase their level of risk. To handle these issues we examine the inter-temporal relationships between risk, capital, and efficiency levels.

Altunbas et al. (2007) argued that examination of the relationship between risk-taking and capital shows contradictory predictions and the main reason is the non-exclusive nature of most of the hypotheses. Jensen (1986) and Berger (1995) argued that trade-offs between capital and bank risk are affected by problems of information asymmetry and agency cost and that is why some banks may react by taking more risks due to the increased capital requirements, while others may decline leverage. By following Altunbas et al. (2007), as theory provides conflicting predictions, we rely on empirical analysis to examine the relationship between risk-taking, capital regulation and efficiency in banks from Bangladesh.

As a consequence of worldwide financial crises, a large number of regulators and researchers have shown their interest to understand and analyze the factors of bank risk-taking including bank capital. Deelchand and Padgett (2009) argued that among other agency problems, managerial incentives, inefficiency, ownership structure, and moral hazard are presented by inappropriate pricing of deposit insurance to affect risk-taking of banks. In this situation, very few studies have focused on the bi-directional relationship between risk-taking, capital regulation, and efficiency (Altunbas et al., 2007; Deelchand \& Padgett, 2009; Fiordelisi et al., 2011; Tan \& Floros, 2013). Besides, there is an increasing number of research interests on capital regulation (Nguyen \& Dang, 2020; Zheng et al., 2017), risk- taking (Hossain, Moudud-Ul-Huq, \& Kader, 2020; Tran, Do, \& Nguyen, 2020), and efficiency (Kumar, Anand, \& Batra, 2020; Moudud-Ul-Huq et al., 2020).

However, this study makes several contributions to the existing literature on the relationship between risk, capital regulation, and efficiency. First, unlike previous studies that focus mainly on the European Union (EU) and the US, this is the first empirical study on the relationship between risk, capital regulation, and efficiency of banks in Bangladesh. Second, while previous related studies use equity to total assets as a proxy for capital (Deelchand \& Padgett, 2009; Fiordelisi et al., 2011), we use capital adequacy ratio i.e. capital to risk-weighted assets as a proxy for capital regulation. Because, according to BASEL I, II, and III capital regulation are imposed to offset the risk of banks. Third, unlike previous studies we use four different types of risk measures (credit risk proxied by non-performing loans to total loans, overall risk proxied by the standard deviation of return on assets, default risk proxied by Z-score, and a new one named liquidity risk proxied by total loans to total deposits) for a greater understanding of risk-taking behaviors and its determinants. Fourth, we include non-traditional activities proxied by off-balance sheet commitments to total assets as an output to calculate the bank's efficiency. Finally, we rely on the Generalized Methods of Moments (GMM) system estimator to count for both potential endogeneity and serial correlation problems.

The remainder of the paper is arranged as follows. Section 2 presents data and variables. Section 3 explains the econometric modeling. Section 4 deals with the empirical results along with hypotheses testing and section 5 concludes and provides suggestions to stakeholders.

\section{Data and Variables}

At the end of 2013, 57 commercial banks are working in Bangladesh that consist of 39 private-owned banks, four state-owned banks, nine foreign-owned banks, and five stateowned specialized banks. The owners of the private-owned banks are private investors. The owner of the state-owned banks is the Government of Bangladesh. The owners of foreign banks are foreign investors. In most of the cases, the branch of foreign banks are operating in Bangladesh, but they report their financial statements separately for Bangladeshi parts. The owner of the state-owned specialized banks is the government, but these banks are run for specialized activities and not for commercial purposes. Our panel includes data of 30 Bangladeshi commercial banks covering a period of 2006-2018. Five specialized banks are excluded from our sample because they do not run for commercial purposes. 17 private-owned commercial banks are also excluded from the sample as some of them are very new and for some the data is unavailable. Likewise, due to the unavailability of data, five foreign-owned banks are also excluded from our sample. As 
the information for all banks is not available for all years, we use an unbalanced panel data. Finally, the samples comprise 30 banks in Bangladesh and a long period from 2006 to 2018.

The main objective of this paper is to examine the relationship between risk, capital regulation, and inefficiency of banks. Therefore the main variables of the study are capital regulation, risk, and inefficiency. For risk measures, we rely on accounting measures of risk. The data for capital regulation and risk measures are extracted mainly from the published annual reports of all banks as well as from the bank's website. The data for inefficiency is derived by using Stochastic Frontier Analysis (SFA). We use some bank- specific, industry-specific, and macroeconomic variables that may affect the relationship between risk, capital regulation, and inefficiency. The data for bank-level control variables (SIZE, CTI, ID, LABOR, OETA, OFBSTA, ROA, TAX, TLTA, GOVS, OWND, LLPTL, and CVALUE) is also extracted from published annual reports and the bank's website. The data for industry-specific variables (CONC, $\mathrm{BSD}$, and CMD) macroeconomic variables (INFR, GGDP) is collected from the website of Bangladesh Bank (http:// www.bangladesh-bank.org) and the database of World Bank (http://data.worldbank.org). Table 4 depicts the definition and list of variables used for our study.

Table 1: Description of the Variables

\begin{tabular}{|c|c|c|c|}
\hline \multicolumn{2}{|c|}{ Variables } & Symbol & Definition \\
\hline \multicolumn{4}{|c|}{ Main Variables } \\
\hline \multicolumn{2}{|c|}{ Capital Regulation } & CAP & $\begin{array}{l}\text { Regulatory capital to risk-weighted assets, i.e. Capital Adequacy } \\
\text { Ratio (CAR) }\end{array}$ \\
\hline \multirow[t]{4}{*}{ Risk } & Credit risk & NPLTL & Ratio of nonperforming loans to total loans \\
\hline & Overall risk & SROA & Standard deviation of return on assets (Volatility in $\mathrm{ROA}$ ) \\
\hline & Default risk & Z-SCORE & Ratio between ROA plus CAR and the standard deviation of ROA \\
\hline & Liquidity risk & TLTD & Ratio of total loans to total deposits \\
\hline \multicolumn{2}{|c|}{ Inefficiency } & INEFF & Derived by using SFA \\
\hline \multicolumn{4}{|c|}{ Bank-level Control Variables } \\
\hline \multicolumn{2}{|c|}{ Bank size } & SIZE & Natural logarithm of total assets \\
\hline \multicolumn{2}{|c|}{ Cost to income } & CTI & Ratio of cost to income \\
\hline \multicolumn{2}{|c|}{ Income diversification } & ID & Ratio of non-interest income to total income \\
\hline \multicolumn{2}{|c|}{ Labor efficiency } & LABOR & Ratio of gross total revenue to the number of employees \\
\hline \multicolumn{2}{|c|}{ Operating Expenses } & OETA & Ratio of operating expenses to total assets \\
\hline \multicolumn{2}{|c|}{ Nontraditional activity } & OFBSTA & Ratio of off-balance sheet items to total assets \\
\hline \multicolumn{2}{|c|}{ Profitability } & $\mathrm{ROA}$ & Return on Assets \\
\hline \multicolumn{2}{|c|}{ Taxation } & TAX & Ratio of tax to pre-tax profit \\
\hline \multicolumn{2}{|c|}{ Total loan to total assets } & TLTA & Ratio of total loans to total assets \\
\hline \multicolumn{2}{|c|}{ Government Securities } & GOVS & Ratio of investment in government securities to total assets \\
\hline \multicolumn{2}{|c|}{ Charter value } & CVALUE & $\begin{array}{l}\text { Ratio between the market value of equity plus book value of liabilities } \\
\text { and book value of total assets }\end{array}$ \\
\hline \multicolumn{2}{|c|}{ Ownership dummy } & OWND & $\begin{array}{l}\text { Equals } 1 \text { if the banks is a private commercial bank and } 0 \text { for } \\
\text { otherwise }\end{array}$ \\
\hline \multicolumn{4}{|c|}{ Industry-Specific Variables } \\
\hline \multicolumn{2}{|c|}{ Banking sector development } & BSD & The ratio of banking industry assets to total gross domestic products \\
\hline \multicolumn{2}{|c|}{ Capital market development } & CMD & $\begin{array}{l}\text { The ratio of the market capitalization of ordinary shares of banks to } \\
\text { total gross domestic products }\end{array}$ \\
\hline \multicolumn{2}{|c|}{ Concentration } & CONC & $\begin{array}{l}\text { Ratio of large three banks in terms of total assets to the total assets } \\
\text { of the banking industry }\end{array}$ \\
\hline \multicolumn{4}{|c|}{ Macroeconomic Variables } \\
\hline \multicolumn{2}{|c|}{ Inflation rate } & INFR & Annual inflation rate \\
\hline \multicolumn{2}{|c|}{ Growth in GDP } & GGDP & Annual growth in real gross domestic product \\
\hline
\end{tabular}




\section{Econometric Model}

We use three simultaneous equations to examine the relationships between risk, capital regulation, and inefficiency by following the approach of Tan and Floros (2013), Altunbas et al. (2007), Deelchand and Padgett (2009), Fiordelisi et al. (2011), Moudud-Ul-Huq (2018), Moudud-Ul-Huq et al. (2018), Moudud-Ul-Huq (2019a), Moudud-Ul-Huq (2019b), and Moudud-Ul-Huq (2020).

We specify our empirical model by three simultaneous equations as:

$$
\begin{aligned}
& \mathrm{CAP}_{\mathrm{it}}=\alpha+\beta_{1} \text { RISK }_{\mathrm{it}}+\beta_{2} \mathrm{INEFF}_{\mathrm{it}}+\beta_{3} \mathrm{SIZE}_{\mathrm{it}}+\beta_{4} \mathrm{CONC}_{\mathrm{i}} \\
& +\beta_{5} \text { LLPTL }_{\text {it }}+\beta_{6} \text { LABOR }_{\text {it }}+\beta_{7} \text { ROA }_{i t}+\beta_{8} \text { TAXit } \\
& +\beta_{9} \text { CTIit }+\beta_{10} \text { OWND }_{i}+\beta_{11} \text { INFR }_{t}+\beta_{12} \text { GGDP }_{t} \\
& +\beta_{13} \mathrm{CMD}_{\mathrm{t}}+\beta_{14} \mathrm{BSD}_{\mathrm{t}}+\varepsilon_{\mathrm{it}} \\
& \text { RISK }_{\text {it }}=\alpha+\beta_{1} \text { CAP }_{\text {it }}+\beta_{2} \text { INEFF }_{\text {it }}+\beta_{3} \text { SIZEit }_{t} \\
& +\beta_{4} \text { CVALUE }_{\text {it }}+\beta_{5} \text { ROA }_{i t}+\beta_{6} \text { GOVS }_{\text {it }} \\
& +\beta_{7} \text { TAX }_{\text {it }}+\beta_{8} \text { TLTA }+\beta_{9} \text { ID }_{\text {it }}+\beta_{10} \text { OFBSTA }_{\text {it }} \\
& +\beta_{11} \text { OWNDi }+\beta_{12} \text { INFR }_{t}+\beta_{13} \text { GGDP }_{t}+\beta_{14} \text { CMD }_{t} \\
& +\beta_{15} \mathrm{BSD}_{\mathrm{t}}+\varepsilon_{\mathrm{it}}
\end{aligned}
$$

$$
\begin{aligned}
\text { INEFF }_{\text {it }} & =\alpha+\beta_{1} \text { CAP }_{i t}+\beta_{2} \text { RISK }_{i t}+\beta_{3} \text { SIZEit }_{t}+\beta_{4} \text { TLTA }_{i t} \\
& +\beta_{5} \text { LLPTL }_{\text {it }}+\beta_{6} \text { ROA }_{i t}+\beta_{7} \text { TAX }_{i t}+\beta_{8} \text { CTI }_{i t} \\
& +\beta_{9} \text { OETA }_{i t}+\beta_{10} \text { LABOR }+\beta_{11} \text { OWND }_{i} \\
& +\beta_{12} \text { INFR }_{t}+\beta_{13} \text { GGDP }_{t}+\beta_{14} \text { CMD }_{t} \\
& +\beta_{15} \text { BSD }_{t}+\varepsilon_{i t}
\end{aligned}
$$

Where subscript $i$ denote the cross-sectional dimension across banks, and $\mathrm{t}$ denotes the time dimension. Capital Adequacy Ratio (CAR) as defined by BASEL I and II are used as a proxy for capital regulation for banks. According to the capital regulation in Bangladesh, banks have to maintain a minimum capital requirement of $10 \%$ of risk-weighted assets or taka 4000 million whichever is higher. RISK is used as a proxy for the risk of banks. We use four different types of risk measures. Credit risk (NPLTL) is our main risk measure. We use three alternative measures for risk. They are (i) Volatility in ROA (SROA) for measuring overall risk, (ii) Z-SCORE for measuring default risk, and (iii) TLTD for measuring liquidity risk. INEFF is used as a proxy for bank inefficiency which is derived from Stochastic Frontier Analysis (SFA).

We use SIZE, CTI, ID, LABOR, OETA, OFBSTA, ROA, TAX, TLTA, GOVS, OWND, LLPTL, CVALUE, as bank-level control variables, CONC, BSD, CMD as industry-specific control variables, INFR, and GGDP as macroeconomic factors which affect the relationships between risk, capital regulation, and cost inefficiency. $\varepsilon_{\text {it }}$ is the random error term.

Equation (1) explains whether the level of capital is affected by the level of risk and inefficiency, whereas equation (2) shows whether the level of capital and inefficiency reflect the level in bank risk. Finally, equation (3) examines the effect of capital and risk on inefficiency. CAP is the ratio of regulatory capital to risk-weighted assets. The NPLTL is used as the main measure for a bank's risk. A high level of ratio denotes a high level of risk. The volatility in ROA is measured as the standard deviation of ROA. The third alternative measure of risk is the Z-score which is the measure of the distance from insolvency. A high value of the standard deviation of ROA shows a high level of risk, whereas a high value of the Z-score shows a high level of stability. The fourth measure of risk is liquidity risk. A high ratio indicates that there is a high risk of not having enough money to meet the obligations from the deposits when they become due for payments.

We use thirteen bank-level control variables, three industry-specific control variables, and two macroeconomic variables because these variables are important in examining the relationships between risk, capital regulation, and cost inefficiency.

\section{Empirical Results and Discussion}

Empirical discussion is presented in three parts. Part 1 discusses the descriptive statistics of all variables both dependent and independent. Part 2 discusses the correlation among the variables and part 3 explores regression analysis.

\subsection{Descriptive Statistics}

Table 2 shows the descriptive statistics of all variables. The mean of CAR is $11.13 \%$ which is higher than the minimum requirements of BASEL II in Bangladesh (Minimum requirement is $10 \%$ ), whereas the minimum CAR is $-6.01 \%$ and the maximum CAR is $16.84 \%$.

The mean of NPLTL is $5.39 \%$ with a standard deviation of $6.35 \%$, which implies that a major part of the loans is non-performing. NPLTL ranges from a minimum of $3.55 \%$ to a maximum of $44.59 \%$. The means of SROA, Z-SCORE, and TLTD are $0.8765,20.61 \%$, and $82.77 \%$ respectively. On average, the overall risk and liquidity risk are very high. In comparison with SROA and TLTD, the Z-SCORE shows lower stability in banks. The mean TI is $11.69 \%$ which implies that the average cost is $11.69 \%$ more than the efficient frontier. The TI ranges from a minimum of $1.6 \%$ to a maximum of $63.46 \%$ and the standard deviation shows that there is high volatility in cost technical inefficiency. 
Table 2: Descriptive Statistics of All Variables

\begin{tabular}{|c|c|c|c|c|}
\hline Variables & Mean & Max & Min & SD \\
\hline Capital regulation (Capital adequacy ratio), in \% & 11.13 & 16.84 & -6.01 & 2.606 \\
\hline Credit risk (Ratio of non-performing loans to total loans), in \% & 5.39 & 44.59 & 0.193 & 6.351 \\
\hline Overall risk (Standard deviation on return on assets) & 0.87 & 3.91 & 0.275 & 0.788 \\
\hline Default risk (Z-score) & 20.61 & 46.80 & -4.263 & 9.400 \\
\hline Liquidity risk (Ratio of total loans to total deposits), in \% & 82.77 & 108.25 & 50.07 & 10.45 \\
\hline Inefficiency, in \% & 11.68 & 63.46 & 1.600 & 12.47 \\
\hline Natural logarithm of total assets & 11.46 & 13.65 & 9.911 & 0.789 \\
\hline Concentration & 30.54 & 34.46 & 23.39 & 3.189 \\
\hline Income diversification & 28.15 & 65.72 & 3.973 & 10.42 \\
\hline Labor efficiency & 6.027 & 14.59 & 0.633 & 3.050 \\
\hline Ratio of operating expenses to total assets, in \% & 2.458 & 10.02 & 0.739 & 1.557 \\
\hline Ratio of off-balance sheet items to total assets, in \% & 29.64 & 73.14 & 2.981 & 11.19 \\
\hline Return on assets, in \% & 1.335 & 3.540 & -10.28 & 1.317 \\
\hline Ratio of tax to pretax profit, in \% & 43.39 & 94.71 & -57.90 & 17.52 \\
\hline Ratio of total loans to total assets, in \% & 67.61 & 155.4 & 40.30 & 10.33 \\
\hline Ratio of investment in government security to total assets, in \% & 11.98 & 36.05 & 0.000 & 6.670 \\
\hline Ratio of cost to income, in \% & 55.60 & 94.96 & 28.59 & 16.52 \\
\hline Charter value & 1.096 & 2.700 & 0.551 & 0.196 \\
\hline Ownership dummy & 0.884 & 1.000 & 0.000 & 0.320 \\
\hline Annual rate of inflation, in $\%$ & 8.196 & 10.62 & 6.660 & 1.369 \\
\hline Annual rate of growth in gross domestic products, in \% & 6.240 & 6.700 & 5.740 & 0.302 \\
\hline Capital market development & 0.251 & 0.417 & 0.048 & 0.104 \\
\hline Banking sector development & 0.664 & 0.765 & 0.509 & 0.080 \\
\hline
\end{tabular}

\subsection{Correlation Analysis}

The Person's correlation coefficients between variables are depicted in Tables $3 \mathrm{a}$ and $3 \mathrm{~b}$. The main objective of this paper is to examine the relationship between risk-taking, capital regulation, and banks' cost. We use some bank-level control variables, some industry-specific control variables as well as some macroeconomic variables that affect the relationship between risk, capital regulation, and inefficiency.

From Table $3 \mathrm{a}$ and $3 \mathrm{~b}$, it is observed that capital regulation is negatively related to the credit and overall risk proxied by NPLTL and SROA respectively. These relations are significant at a $1 \%$ level of significance. It is also revealed from the table that capital regulation is positively related to default risk and liquidity risk proxied by Z-SCORE and TLTD respectively. These relations are also significant at a $1 \%$ level of significance. Capital regulation is positively related to inefficiency.

Tables $3 \mathrm{a}$ and $3 \mathrm{~b}$ also show that inefficiency is negatively and significantly related to credit and overall risk and positively related to default and liquidity risk. Bank size is negatively related to capital regulation, default risk, liquidity risk, and inefficiency and positively related to credit risk as well as overall risk. All of these relationships are significant at a $1 \%$ level of significance.

Among other variables, CONC, LABOR, ROA, TAX, OWND, GOVS, and CMD have a significant impact on capital. On the other hand, ID, LABOR, OFBSTA, ROA, TAX, TLTA, OWND, GOVS, CTI, and CVALUE have a significant effect on different risks. Finally, ID, OETA, OWND, GOVS, have a significant impact on inefficiency (For details see Table $3 \mathrm{a}$ and $3 \mathrm{~b}$ in Appendices).

The correlation matrix also shows that our models are not suffering from major problems of multicollinearity. According to Dormann et al. (2013) multicollinearity is a serious problem when the absolute value of the correlation coefficient between predictor variables is more than 0.7 . This is also evident from the table that some relations are insignificant and some are ambiguous. Therefore, we need to run a regression analysis to get a real picture of the relationship between risk, capital regulation, and inefficiency. 
Table 3a: Pearson's Correlation Coefficients between the Variables

\begin{tabular}{|l|c|c|c|c|c|c|c|c|c|c|c|}
\hline & CAR & NPLTL & SROA & Z-SCORE & TLTD & INEFF & SIZE & CONC & ID & LABOR & OETA \\
\hline CAR & 1.000 & & & & & & & & & & \\
\hline NPLTL & $-.393^{* * *}$ & 1.000 & & & & & & & & & \\
\hline SROA & $-.370^{* * *}$ & $.879^{* * *}$ & 1.000 & & & & & & & & \\
\hline Z-SCORE & $.444^{* * *}$ & $-.585^{* *}$ & $-.759^{* * *}$ & 1.000 & & & & & & & \\
\hline TLTD & $.206^{* * *}$ & $-.529^{* * *}$ & $-.498^{* * *}$ & $.333^{* * *}$ & 1.000 & & & & & & \\
\hline INEFF & .022 & -.098 & $-.171^{* *}$ & .090 & .114 & 1.000 & & & & & \\
\hline SIZE & $-.258^{* * *}$ & $.594^{* * *}$ & $.622^{* * *}$ & $-.413^{* * *}$ & $.435^{* * *}$ & -.118 & 1.000 & & & & \\
\hline CONC & $.262^{* * *}$ & .063 & .031 & .043 & -.036 & -.009 & $.159^{* *}$ & 1.000 & & & \\
\hline ID & -.101 & $.326^{* * *}$ & $.351^{* * *}$ & $-.173^{* *}$ & -.136 & .105 & $.259^{* * *}$ & .010 & 1.000 & & \\
\hline LABOR & $.226^{* * *}$ & $-.449^{* *}$ & $-.420^{* * *}$ & $.330^{* * *}$ & $.276^{* * *}$ & -.044 & -.013 & .049 & $-.152^{* *}$ & 1.000 & \\
\hline OETA & .063 & -.089 & $-.125^{*}$ & .052 & $.153^{* *}$ & $.917^{* * *}$ & -.065 & -.005 & $.146^{* *}$ & -.108 & 1.000 \\
\hline
\end{tabular}

Note: ${ }^{*},{ }^{* *},{ }^{* *}$ significant at $10 \%, 5 \%$, and $1 \%$ respectively.

Table 3b: Pearson's Correlation Coefficients between the Variables

\begin{tabular}{|l|c|c|c|c|c|c|c|c|c|c|c|c|}
\hline & OFBSTA & ROA & TAX & TLTA & OWND & GOVS & CTI & INFR & GGDP & CMD & BSD & CVALUE \\
\hline OFBSTA & 1.000 & & & & & & & & & & & \\
\hline ROA & $.180^{* *}$ & 1.000 & & & & & & & & & & \\
\hline TAX & .073 & $.252^{* * *}$ & 1.000 & & & & & & & & & \\
\hline TLTA & $.379^{* * *}$ & $.229^{* * *}$ & $.142^{*}$ & 1.000 & & & & & & & & \\
\hline OWND & $.130^{*}$ & $.450^{* * *}$ & $.416^{* \star *}$ & $.352^{* * *}$ & 1.000 & & & & & & & \\
\hline GOVS & .050 & $-.245^{* * *}$ & -.127 & $-.315^{* * *}$ & $-.468^{* * *}$ & 1.000 & & & & & & \\
\hline CTI & $-.317^{* * *}$ & $-.246^{* * *}$ & -.108 & .035 & $-.197^{* * *}$ & -.092 & 1.000 & & & & & \\
\hline INFR & -.096 & $-.194^{* * *}$ & $.141^{*}$ & -.109 & -.031 & .067 & .054 & 1.000 & & & & \\
\hline GGDP & .139 & -.104 & .020 & .041 & .044 & -.086 & -.006 & $.214^{* * *}$ & 1.000 & & & \\
\hline CMD & $-.174^{* *}$ & $.227^{* *}$ & .080 & .054 & -.064 & 0.026 & -.039 & $.161^{* *}$ & $-.546^{* * *}$ & 1.000 & & \\
\hline BSD & -.110 & -.011 & $.127^{*}$ & $-.165^{* *}$ & -.057 & $.152^{* *}$ & -.015 & $.446^{* * *}$ & $-.209^{* * *}$ & $.172^{* *}$ & 1.000 & \\
\hline CVALUE & $.212^{* * *}$ & $.152^{* *}$ & .083 & $.478^{* *}$ & $.152^{* *}$ & -.101 & -.107 & -.128 & -.053 & .134 & -.122 & 1.000 \\
\hline
\end{tabular}

Note: ${ }^{*},{ }^{* *},{ }^{* *}$ significant at $10 \%, 5 \%$, and $1 \%$ respectively.

\subsection{Regression Analysis}

In this study, we apply the GMM system panel estimator developed by Arellano and Bover (1995) and Blundell and Bond (2000). The estimated results from the GMM estimator are presented in Tables 4, 5, and 6. The main risk variable is credit risk proxied by NPLTL. We use three other alternatives of risk measures; they are overall risk proxied by SROA, default risk proxied by Z-SCORE, and liquidity risk proxied by TLTD. The main objective of the study is to examine the relationship between risk-taking, capital regulation, and bank inefficiency. The impacts of bank-level control variables, industry-specific control variables, and macroeconomic variables on the relationship between risk, capital regulation, and inefficiency are also addressed. Regression analyses are divided into three parts: part 1 explains the impact of risk and inefficiency on capital regulation, part 2 focuses on the impact of capital regulation and inefficiency on risk and finally, part 3 shows the impact of capital regulation and risk on inefficiency. 
Table 4: Impact of Risk and Inefficiency on Capital Regulation

\begin{tabular}{|l|c|c|c|c|}
\hline \multirow{2}{*}{ Variables } & Model 1 & Model 2 & Model 3 & Model 4 \\
\cline { 2 - 5 } & RISK=NPLTL & RISK=SROA & RISK=Z-SCORE & RISK=TLTD \\
\hline NPLTL & $-.6458^{* * *}(-2.51)$ & & & \\
\hline SROA & & $-1.4416^{*}(-1.69)$ & & \\
\hline Z-SCORE & & & $0.2734^{*}(1.73)$ & \\
\hline TLTD & & & & $0.0200(0.75)$ \\
\hline INEFF & $0.0039(-0.85)$ & $0.1684(1.36)$ & $0.1797(1.50)$ & $0.1868(0.53)$ \\
\hline SIZE & $-0.2746(-1.05)$ & $0.3685(0.72)$ & $-0.3248(-1.23)$ & $0.4563(1.49)$ \\
\hline ROA & $1.3369^{* * *}(8.38)$ & $1.4430^{* * *}(6.03)$ & $1.1892^{* * *}(5.73)$ & $1.2753^{* * *}(7.49)$ \\
\hline TAX & $0.0441^{* * *}(3.45)$ & $0.0274^{*}(1.79)$ & $0.0280^{* * *}(2.71)$ & $0.0388^{* *}(2.06)$ \\
\hline LABOR & $0.0618^{*}(1.73)$ & $0.0840(0.72)$ & $0.0076(0.08)$ & $-0.0172(-0.28)$ \\
\hline CONC & $0.1713^{*}(1.78)$ & $0.3105^{* * *}(4.24)$ & $0.3171^{* * *}(4.02)$ & $0.2924^{* * *}(3.91)$ \\
\hline CTI & $0.0188^{* *}(1.91)$ & $0.0393^{* *}(2.13)$ & $0.0474^{*}(1.73)$ & $0.0181(1.17)$ \\
\hline LLPTL & $-0.5604^{*}(-1.83)$ & $0.8365^{*}(1.89)$ & $0.2236^{* *}(2.45)$ & $0.2026^{*}(1.78)$ \\
\hline OWND & $3.6769^{* * *}(3.72)$ & $3.5836^{* *}(2.28)$ & $2.5543^{*}(1.73)$ & $2.3875^{* *}(1.97)$ \\
\hline CMD & $3.1075^{*}(1.70)$ & $4.9093^{*}(1.69)$ & $1.4444^{* *}(2.13)$ & $2.0122^{*}(1.72)$ \\
\hline BSD & $-2.8941(-0.69)$ & $-3.0127(-0.89)$ & $-6.0225^{*}(-1.77)$ & $-5.1245^{*}(-1.66)$ \\
\hline INFR & $-0.1009(-0.59)$ & $-0.1968(-0.81)$ & $0.0747(0.52)$ & $-0.0026(-0.48)$ \\
\hline GGDP & $0.2144(0.43)$ & $1.6473^{*}(1.69)$ & $0.5130(0.84)$ & $0.2003(0.59)$ \\
\hline Adjusted R-squared & 44.45 & 49.37 & 42.61 & 49.03 \\
\hline Hausman test, F $(p-v a l u e)$ & $18 . .23(.000)$ & $22.33(.000)$ & $25.57(.000)$ & $23.16(.000)$ \\
\hline Sargan test $(p-v a l u e)$ & 0.476 & 0.415 & 0.204 & 0.318 \\
\hline $\begin{array}{l}\text { Serial correlation test } \\
\text { (p-value) }\end{array}$ & 0.817 & 0.758 & 0.795 & 0.617 \\
\hline Observations & 280 & 280 & 280 & 33 \\
\hline Number of banks & 33 & 33 & 33 & \\
\hline
\end{tabular}

Notes: The table shows the empirical results from the GMM panel estimator. The dependent variable is capital for all four models. *** ${ }^{* *}$ and * indicate significance at $1 \%, 5 \%$ and $10 \%$ respectively. For the Hausman test, p-values are in parentheses. t-statistics are also shown in parentheses.

\subsubsection{Impact of Risk and Inefficiency on Capital Regulation}

Empirical results obtained from the simultaneous equation using capital regulation as the dependent variable are presented in Table 4. The empirical results show that there is a negative and significant relationship between risk (NPLTL and SROA) and capital, which implies that banks with lower risk hold more capital i.e. when capital increases, credit risk and overall risk decrease.

On the other hand, the relationship is positive when Z-SCORE and TLTD are used as a proxy for risk. This implies that banks with high liquidity risk and high Z-SCORE hold more capital. It is also seen from the table that the relationship between capital and inefficiency is positive which implies that inefficient banks hold more capital and the results are the same for all four models. These results support evidence of incentives for moral hazard (Deelchand \& Padgett, 2009).

Bank size is negatively related to capital which suggests that large banks hold a lower amount of capital. This is because the larger banks have easy access to capital and can increase capital easily with lower transaction costs. According to our expectation, we see there is a positive significant relationship between ROA and capital, such that banks with a high level of profitability ratio also tend to operate with a high level of capital. 
Table 5: Impact of Capital Regulation and Inefficiency on Risk

\begin{tabular}{|l|c|c|c|c|}
\hline \multirow{2}{*}{ Variables } & Model 5 & Model 6 & Model 7 & Model 8 \\
\cline { 2 - 5 } & RISK=NPLTL & RISK=SROA & RISK=Z-SCORE & RISK=TLTD \\
\hline CAR & $-1.0064^{*}(-1.54)$ & $-0.023^{*}(-1.76)$ & $0.545^{*}(1.65)$ & $1.965^{* *}(1.89)$ \\
\hline INEFF & $0.6306^{*}(1 . .58)$ & $0.001^{*}(1.77)$ & $-0.989^{*}(-1.72)$ & $-0.188(-1.25)$ \\
\hline SIZE & $1.8858^{* *}(2.13)$ & $0.268^{* * *}(4.65)$ & $0.906^{*}(1.67)$ & $0.310(1.22)$ \\
\hline CVALUE & $-1.3749^{*}(-1.69)$ & $0.284(0.97)$ & $-5.666^{*}(-1.74)$ & $-5.531^{*}(-1.73)$ \\
\hline ROA & $-2.090^{* * *}(-2.44)$ & $-0.063(-1.01)$ & $1.109(0.73)$ & $-2.117^{*}(-1.67)$ \\
\hline TAX & $-0.103^{* * *}(-3.42)$ & $-0.004^{*}(-1.78)$ & $0.058^{*}(1.61)$ & $-0.098^{* *}(-2.04)$ \\
\hline GOVS & $-0.011(-0.14)$ & $-0.020^{* *}(-3.34)$ & $0.392^{* * *}(2.66)$ & $-0.616^{* * *}(-4.67)$ \\
\hline TLTA & $-0.193^{* * *}(-3.12)$ & $-0.007^{*}(-1.62)$ & $-0.089(-0.81)$ & $0.474^{* * *}(4.81)$ \\
\hline OFBSTA & $0.047^{*}(1.68)$ & $0.091^{*}(1.72)$ & $0.706^{*}(1.78)$ & $0.216(0.52)$ \\
\hline ID & $0.043^{*}(1.68)$ & $0.001(0.58)$ & $0.061(1.01)$ & $0.092(1.46)$ \\
\hline OWND & $-7.226^{* * *}(-3.41)$ & $-1.59^{* * *}(-10.57)$ & $20.020^{* * *}(6.73)$ & $11.023^{* * *}(3.53)$ \\
\hline CMD & $12.981^{* * *}(2.93)$ & $0.569(1.08)$ & $10.993(1.29)$ & $9.737(1.28)$ \\
\hline BSD & $18.421^{* * *}(3.73)$ & $1.288^{*}(1.76)$ & $11.93^{*}(1.71)$ & $1.09(0.08)$ \\
\hline INFR & $0.5788^{* * *}(2.66)$ & $0.017(0.71)$ & $-0.1169(-0.22)$ & $0.480(0.89)$ \\
\hline GGDP & $-1.282^{*}(-1.57)$ & $0.163^{*}(1.67)$ & $1.0269(0.44)$ & $4.358^{* *}(2.15)$ \\
\hline Adjusted R-squared & 77.79 & 79.66 & 43.93 & 50.22 \\
\hline Hausman test, F (p-value) & $35.26(.000)$ & $28.62(.000)$ & $19.48(.000)$ & $22.86(.000)$ \\
\hline Sargan test $(p-v a l u e)$ & 0.832 & 0.524 & 0.716 & 0.458 \\
\hline Serial correlation test $(\mathrm{p}$-value) & 0.274 & 0.197 & 0.234 & 0.417 \\
\hline Observations & 280 & 280 & 280 & 280 \\
\hline Number of banks & 33 & 33 & 33 & 33 \\
\hline
\end{tabular}

Notes: The table shows the empirical results from the GMM panel estimator. The dependent variable is the risk for all four models measured by NPLTL, SROA, Z-SCORE, and TLTD for Model $5,6,7$, and 8 respectively. ${ }^{* * *}$, ${ }^{* *}$ and ${ }^{*}$ indicate significance at the $1 \%, 5 \%$ and $10 \%$ respectively. For the Hausman test, p-values are in parentheses. t-statistics are shown in parentheses.

Higher taxation paid by banks creates pressure to increase capital because a huge amount of cash is usually forgone through tax. CONC shows a positive significant relationship with capital. It means that banks in a highly concentrated banking market are usually better capitalized. Labor efficient banks hold more capital as the manager from banks are taking part in decision-making concerning capital. Loan loss provision has a negative significant impact on capital and the impact is positive when SROA, Z-SCORE, and TLTD are used as a proxy for risk. A higher level of cost to income ratio is positively related to capital which suggests that in an inefficient system, the banks hold more capital. Ownership is positively related to capital which suggests that private commercial banks in Bangladesh hold more capital. As the capital market develops, banks can generate more capital from the capital market through issuing shares which are reflected by a positive sign between CMD and capital. As the banking sector develops, the banks hold lower capital and this is because of huge competition in a small economy. Inflation and GGDP have a negative and positive impact respectively on capital, but these relations are not statistically significant.

\subsubsection{Impact of Capital Regulation and Inefficiency on Risk}

Table 5 presents the empirical results by using a simultaneous equation (Equation 2) where risk is used as the dependent variable. Four different types of accounting measures of risks (NPLTL, SROA, Z-SCORE, and TLTD) are used as the dependent variable. The results confirm the findings presented previously. The CAR is negatively and significantly related to credit risk and overall risk which implies that banks with a low level of capital take more risks. As the CAR increases, the credit and overall risk decrease. It may show the problem of moral hazard where banks take advantage of the gains of deposit insurance. 
Table 6: Impact of Capital Regulation and Risk on Inefficiency

\begin{tabular}{|l|c|c|c|c|}
\hline \multirow{2}{*}{ Variables } & Model 9 & Model 10 & Model 11 & Model 12 \\
\cline { 2 - 5 } & RISK=NPLTL & RISK=SROA & RISK=Z-SCORE & RISK=TLTD \\
\hline CAR & $0.257^{*}(1.71)$ & $0.294^{*}(1.72)$ & $0.905^{*}(1.70)$ & $-0.478(-0.70)$ \\
\hline NPLTL & $0.625^{*}(1.68)$ & & & \\
\hline SROA & & $1.668(0.56)$ & & \\
\hline Z-SCORE & & & $-0.130(-0.36)$ & \\
\hline TLTD & & & & $-0.27^{* * *}(-3.55)$ \\
\hline SIZE & $-1.043(-0.95)$ & $-0.549(-0.47)$ & $-0.070(-1.09)$ & $0.643(0.72)$ \\
\hline ROA & $-0.971(-0.55)$ & $-0.879(-0.94)$ & $-1.039^{*}(-1.68)$ & $0.735(0.81)$ \\
\hline TAX & $0.037(0.58)$ & $0.027(0.76)$ & $0.013(0.38)$ & $0.032(0.63)$ \\
\hline OETA & $7.65^{* * *}(32.00)$ & $7.33^{* * *}(26.21)$ & $7.30^{* * *}(25.61)$ & $7.40^{* * *}(30.26)$ \\
\hline LABOR & $0.44^{* * *}(2.77)$ & $0.393^{* *}(1.92)$ & $0.397^{*}(1.78)$ & $0.539(1.34)$ \\
\hline TLTA & $-0.18^{* * *}(-3.93)$ & $-0.19^{* * *}(-4.33)$ & $-0.19^{* * *}(-4.23)$ & $-0.034(-0.66)$ \\
\hline LLPTL & $-0.662(-1.36)$ & $-0.443(-0.70)$ & $-0.31^{* *}(-1.90)$ & $-0.305^{*}(-1.82)$ \\
\hline OWND & $6.965(1.34)$ & $3.408(0.66)$ & $3.249(0.49)$ & $5.547^{* *}(2.28)$ \\
\hline CMD & $5.796(1.27)$ & $5.248(1.02)$ & $6.300(1.10)$ & $5.663(1.05)$ \\
\hline BSD & $-22.12^{* * *}(-2.78)$ & $-22.01^{* * *}(-2.63)$ & $-23.16^{* *}(-2.18)$ & $-23.43^{* *}(-2.32)$ \\
\hline INFR & $-0.083(-0.25)$ & $0.216(0.52)$ & $0.197(0.47)$ & $0.137(0.22)$ \\
\hline GGDP & $1.812^{*}(1.69)$ & $1.690(0.98)$ & $1.908(1.44)$ & $1.907(1.42)$ \\
\hline Adjusted R-squared & 83.41 & 79.79 & 79.72 & 84.61 \\
\hline Hausman test, F (p-value) & $23.44(.000)$ & $19.12(.000)$ & $22.13(.000)$ & $18.75(.000)$ \\
\hline Sargan test (p-value) & 0.613 & 0.523 & 0.641 & 0.433 \\
\hline Serial correlation test $(p-v a l u e)$ & 0.298 & 0.312 & 0.282 & 0.541 \\
\hline Observations & 280 & 280 & 280 & 280 \\
\hline Number of banks & 33 & 33 & 33 & 33 \\
\hline
\end{tabular}

Notes: The table shows the empirical results from the GMM panel estimator. The dependent variable is INEFF (in efficiency) for all four models. ${ }^{* *},{ }^{* *}$ and ${ }^{*}$ indicate significance at the $1 \%, 5 \%$ and $10 \%$ respectively. For the Hausman test, p-values are in parentheses. t-statistics are shown in parentheses.

CAR is positively and significantly related to default and liquidity risk i.e. banks with a high level of capital are more stable and take high liquidity risk. Table 10 also shows that inefficiency is negatively and significantly related to credit and overall risk whereby the relationship is positive and significant for default risk and liquidity risk. It suggests that inefficient banks are more vulnerable to credit and overall risk-taking than efficient ones. On the other hand, the negative relation between risk and inefficiency implies that efficient banks are more stable and take more liquidity risk. The positive sign between bank size and risk suggests that larger banks take more risk as well as are more stable.

CVALUE is negatively and significantly related to risk which means that banks with lower charter value take more risk to compensate for the reduction in charter value. Off-balance sheet activities are positively and significantly related to risk suggesting that banks with more non-traditional activities take more risk. ROA is negatively and significantly related to NPLTL, SROA, TLTD, and positively related to Z-SCORE which concludes that banks with high profitability take a low risk and are more stable than banks with low profitability. Banks paying high taxes take more risks and are more stable. In Bangladesh, banks invest in government securities to reduce risk of return and the negative significant relationship between GOVS and risk confirms that. It is also evident that banks with a high investment in government securities are more stable than those having low investment in government securities. Total loan to total assets ratio is negatively and significantly related to the credit risk, overall risk, and default risk but positively related to liquidity risk. Off-balance sheet activities are positively and significantly related to risk. Banks with more income diversification take more risk. 
OWND is negatively and significantly related to credit risk and overall risk. On the other hand, OWND is positively and significantly related to default and liquidity risk. This implies that private commercial banks take a lower level of credit and overall risk. They are more stable and take high liquidity risk. Capital market development is positively related to risk which indicates that as the capital market develops, banks take more risk. There is a positive and significant association between banking sector developments and risk. It means that as the banking sector develops banks in Bangladesh take more risk. Inflation and growth in real GDP have a positive and significant impact on risk.

\subsubsection{Impact of Capital Regulation and Risk on Inefficiency}

Table 6 presents the empirical results for equation (3) where cost technical inefficiency is used as the dependent variable. The results confirm the results presented earlier. For example, there is a positive association between inefficiency and capital. It implies that in comparison with under-capitalized banks, better-capitalized banks operate less efficiently. Credit and overall risk are positively and significantly related to inefficiency. This is due to a large number of loans. Default risk and liquidity risks are negatively and significantly related to inefficiency. It suggests that banks with high stability are more efficient banks and banks with more liquidity risk are also efficient.

It is also seen from the table that bank size is negatively related to inefficiency which means that large banks are more cost-efficient in comparing with small banks. ROA is negatively related to inefficiency which suggests that banks with high profitability are more efficient. Tax is positively related to inefficiency. It means that bank managers paying higher taxes have no control over the costs for tax, as a result, input expenses increase and efficiency decreases. Operating expenses are positively and significantly related to inefficiency. As operating expenses increase the input expenses also increase which leads to a reduction in technical efficiency.

LABOR is positively and significantly related to inefficiency. This is because labor with high labor efficiency demands higher salaries which leads to an increase in the input prices and there is a decline in technical efficiency. The amount of loans is significantly and negatively related to cost technical inefficiency. It implies that as the number of loans increases, the output of banks increases which leads to an increase in efficiency.

Loan loss provision is negatively and significantly related to inefficiency i.e. efficient banks keep more provision for loan losses. Ownership is positively related to inefficiency which suggests that private commercial banks are more cost-inefficient than state-owned commercial banks. Capital market development is positively related to inefficiency and this relationship is not statistically significant. Banking sector development is negatively and significantly related to inefficiency. As banking assets increase the outputs of banks increase which leads to an increase in efficiency. INFR and GGDP do not have a significant impact on cost technical inefficiency.

Here, risk, capital, and inefficiency are simultaneously determined as the p-value of the Hausman test is significant for all models in the aforesaid equations. The Sargan test also reports that all models' instruments are valid and other indicators also verify the model fitness.

\section{Conclusions}

In this paper, we examine the interrelationships between risk-taking, capital regulation, and efficiency for commercial banks in Bangladesh from 2006 to 2018. We examine the relationship by including regulatory capital and cost technical inefficiency derived by using a computer program named Frontier Version 4.1 developed by Coelli (1996) and four measures of risk with introducing a new risk measure called liquidity risk. We use bank-level control variables, industryspecific variables as well as macroeconomic variables that affect the relationship between risk-taking, capital regulation, and efficiency. For the potential endogeneity problem, the GMM panel data estimator technique is used to examine the relationships. The results confirm that risk, capital regulation, and inefficiency are simultaneously determined. We use CAR as a proxy for capital regulation, four different measures of risk (NPLTL as a proxy for credit risk, SROA as a proxy for overall risk, Z-SCORE as a proxy for default risk, and TLTD as a proxy for liquidity risk), cost technical inefficiency as a proxy for inefficiency. We contribute to the existing empirical literature by using Bangladeshi banking data from 2006 to 2018, a new risk measure called liquidity risk proxied by total loans to total deposits and more number of control variables.

Our empirical results show that there is a negative significant relationship between CAR and credit risk and overall risk which implies that as banking regulatory capital increases, the credit and overall risk of banks decreases. We can say that the objective of BASEL is attained. It is also evident from the results that the CAR is positively and significantly related to default risk and liquidity risk. It means that as the regulatory capital increases, the stability and liquidity risk also increases. Our results also report that banks with a high level of cost technical inefficiency hold a low level of capital and take a high level of credit and overall risk. This supports the behavior of moral hazard whereby inefficient banks are interested to engage in more risk-taking activities. On the other hand, efficient banks are more stable and take a high level of liquidity risk. 
In the case of the bank-level control variables, the results show that large banks hold a lower level of regulatory capital and take more risk with more stability, and are more cost-efficient. More profitable banks hold more capital; take a lower level of risk and are more cost-efficient. Banks paying high taxes hold more capital, take less risk, and are less cost-efficient. In the concentrated banking industry, banks hold more capital. Banks with loan loss provisions hold more capital and are more cost-efficient. In terms of industry-specific control variables, empirical results also show that for capital market development banks hold more capital, take more risk, and become more cost-inefficient. As the banking sector develops, banks hold less capital, take more risk, and become more cost-efficient. Private commercial banks hold more capital, take low risk, and are more cost-inefficient. In terms of macroeconomic control variables, the results also present that inflation has a negative impact on capital and a positive impact on risk and inefficiency. Finally, growth in the gross domestic product has a positive impact on capital, risk, and inefficiency. However, there are some limitations to this paper. First, unlike Shrieves and Dahl (1992) we have focused our analysis on levels of risk, capital regulation, and inefficiency rather than changes. This is mostly due to the small sample period as well as the unavailability of data for all years for all banks. Second, we have focused only on cost technical inefficiency. Future studies should be done to examine the consistency of findings by using changes in variables, alternative accounting, and marketbased measures of banking risk, profit efficiency measure, and factors affecting BASEL capital strength.

\section{References}

Altunbas, Y., Carbo, S., Gardener, E. P. M., \& Molyneux, P. (2007). Examining the relationships between capital, risk, and efficiency in European banking. European Financial Management, 13(1), 49-70. https://doi.org/10.1111/j.1468-036X.2006.00285.x

Arellano, M., \& Bover, O. (1995). Another look at the instrumental variable estimation of error-components models. Journal of Econometrics, 68(1), 29-51.https://doi.org/10.1016/03044076(94)01642-D

Berger, A. N. (1995). The relationship between capital and earnings in banking. Journal of Money, Credit and Banking, 27(2), 432-456. https://doi.org/10.2307/2077877

Blundell, R., \& Bond, S. (2000). GMM estimation with persistent panel data: An application to production functions. Econometric Reviews, 19(3), 321-340. https://doi. org 10.1080/07474930008800475

Coelli, T. J. (1996). A guide to FRONTIER Version 4.1: A computer program for Stochastic Frontier Production and Cost Function Estimation. CEPA Working Paper No. 7/96, Department of Econometrics, University of New England, Armidale.
Available at: http://www.uq.edu.au/economics/cepa/frontier. php

Danthine, J.-P., Giavazzi, F., Vives, X., \& Thadden, E.-L. V. (1999). Monitoring European integration: The future of European banking. London: CEPR.

Deelchand, T., \& Padgett, C. (2009). The relationship between risk, capital, and efficiency: Evidence from Japanese cooperative banks. ICMA Centre Discussion Papers in Finance DP2009-12. Available at: https://dx.doi.org/10.2139/ssrn.1525423

Dormann, C. F., Elith, J., Bacher, S., Buchmann, C., Carl, G., Carré, G., Marquez, J .R. G., Gruber, B., Lafourcade, B., Leitao, P. J., Munkemuller, T., McClean, C., Osborne, P. E., Reineking, B., Schroder, B., Skidmore, A. K., Zurell, D., \& Lautenbach, S. (2013). Collinearity: a review of methods to deal with it and a simulation study evaluating their performance. Ecography, 36(1), 27-46. https://doi.org/ 10.1111/j.16000587.2012.07348.x

Festic, M., Kavkler, A., \& Repina, S. (2011). The macroeconomic sources of systemic risk in the banking sectors of five new EU member states. Journal of Banking \& Finance, 35(2), 310-322. http://dx.doi.org/10.1016/j.jbankfin.2010.08.007

Fiordelisi, F., Marques-Ibanez, D., \& Molyneux, P. (2011). Efficiency and risk in European banking. Journal of Banking \& Finance, 35(5), 1315-1326. http://dx.doi.org/10.1016/j. jbankfin.2010.10.005

Goddard, J., \& Wilson, J. O. S. (2009). Competition in banking: A disequilibrium approach. Journal of Banking \& Finance, 33(12), 2282-2292. http://dx.doi.org/10.1016/j.jbankfin.2009.06.003

Hellmann, T. F., Murdock, K. C., \& Stiglitz, J. E. (2000). Liberalization, moral hazard in banking, and prudential regulation: Are capital requirements enough? American Economic Review, 90(1), 147-165. https://doi.org/10.1257/ aer.90.1.147

Hossain, S. A., Moudud-Ul-Huq, S., \& Kader, M. B. (2020). Impact of trade openness on bank risk-taking behavior: Evidence from a developing country. Cogent Economics \& Finance, 8(1), 147-165. https://doi.org/10.1080/23322039.2020.1765468

Jensen, M. C. (1986). Agency Cost Of Free Cash flow, corporate finance, and takeovers. American Economic Review, 76(2), 323-329. doi: http://dx.doi.org/10.2139/ssrn.99580

Kumar, A., Anand, N., \& Batra, V. (2020). Trends in Indian private sector bank efficiency: Non-Stochastic Frontier DEA Window analysis approach. Journal of Asian Finance, Economics, and Business, 7(10), 729-740. https://doi.org/10.13106/jafeb.2020. vol7.n10.729

Moudud-Ul-Huq, S. (2018). Banks' capital buffers, risk, and efficiency in emerging economies: Are they counter-cyclical? Eurasian Economic Review, 9, 1-26. https://doi.org/10.1007/ s40822-018-0121-5

Moudud-Ul-Huq, S. (2019a). Banks' capital buffers, risk, and efficiency in emerging economies: are they counter-cyclical? Eurasian Economic Review, 9(4), 467-492. https://doi. org/10.1007/s40822-018-0121-5 
Moudud-Ul-Huq, S. (2019b). Can BRICS and ASEAN-5 emerging economies benefit from bank diversification? Journal of Financial Regulation and Compliance, 27(1), 43-69. https:// doi.org/10.1108/JFRC-02-2018-0026

Moudud-Ul-Huq, S. (2020). Does bank competition matter for performance and risk-taking? Empirical evidence from BRICS countries. International Journal of Emerging Markets, ahead-of-prin(ahead-of-prin). doi: https://doi.org/10.1108/ IJOEM-03-2019-0197

Moudud-Ul-Huq, S., Ashraf, B. N., Gupta, A. D., \& Zheng, C. (2018). Does bank diversification heterogeneously affect performance and risk-taking in ASEAN emerging economies? Research in International Business and Finance, 46, 342-362.

Moudud-Ul-Huq, S., Zheng, C., Gupta, A. D., Hossain, S. K. A., \& Biswas, T. (2020). Risk and performance in emerging economies: Do bank diversification and financial crisis matter? Global Business Review, 1-27. doi: 10.1177/0972150920915301

Nguyen, H. D. H., \& Dang, V. D. (2020). Bank-specific determinants of loan growth in Vietnam: evidence from the CAMELS approach. Journal of Asian Finance, Economics, and Business, 7(9), 179-189. https://doi.org/10.13106/jafeb.2020. vol7.no9.179
Salas, V., \& Saurina, J. (2003). Deregulation, market power, and risk behavior in Spanish banks. European Economic Review, 47(6), 1061-1075. doi: http://dx.doi.org/10.1016/S00142921(02)00230-1

Shrieves, R. E., \& Dahl, D. (1992). The relationship between risk and capital in commercial banks. Journal of Banking \& Finance, 16(2), 439-457. http://dx.doi.org/10.1016/03784266(92)90024-T

Tan, Y., \& Floros, C. (2013). Risk, capital, and efficiency in Chinese banking. Journal of International Financial Markets, Institutions, and Money, 26, 378-393. https://doi.org/10.1016/j. intfin.2013.07.009

Tran, T. T., Do, N. H., \& Nguyen, Y. T. (2020). Impact of board characteristics on bank risk: The case of Vietnam. Journal of Asian Finance, Economics, and Business, 7(9), 377-388. https://doi.org/10.13106/jafeb.2020.vol7.no9.377

Zheng, C., Moudud-Ul-Huq, S., Rahman, M. M., \& Ashraf, B. N. (2017). Does the ownership structure matter for banks' capital regulation and risk-taking behavior? Empirical evidence from a developing country. Research in International Business and Finance, 42, 404-421. https://doi.org/10.1016/j. ribaf.2017.07.035 